See discussions, stats, and author profiles for this publication at: https://www.researchgate.net/publication/257694797

\title{
Sistotremastrum guttuliferum: A new species from the Macaronesian islands
}

Article in Mycological Progress · October 2013

DOI: 10.1007/s11557-012-0876-0

7 authors, including:

M. Teresa Telleria

Spanish National Research Council

186 PUBLICATIONS 6,826 CITATIONS

SEE PROFILE

Margarita Dueñas

Spanish National Research Council

144 PUBLICATIONS 6,275 CITATIONS

SEE PROFILE

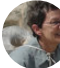

Ireneia Melo

National Museum of Natural History and Science

115 PUBLICATIONS 1,014 CITATIONS

SEE PROFILE

Isabel Salcedo

Universidad del País Vasco / Euskal Herriko Unibertsitatea 158 PUBLICATIONS 955 CITATIONS

SEE PROFILE

Some of the authors of this publication are also working on these related projects:

Review of the genus Calvatia fr. (Lycoperdacae, Agaricomycetidae): integration of morphological and molecular data View project

El manejo nutricional como herramienta de mejora para la calidad de planta forestal y del suelo View project 


\title{
Sistotremastrum guttuliferum: a new species from the Macaronesian islands
}

\author{
M. Teresa Telleria • Ireneia Melo • Margarita Dueñas • \\ Isabel Salcedo • Esperanza Beltrán-Tejera • \\ J. Laura Rodríguez-Armas • María P. Martín
}

Received: 27 September 2012 /Revised: 27 November 2012 / Accepted: 1 December 2012 /Published online: 19 December 2012

(C) German Mycological Society and Springer-Verlag Berlin Heidelberg 2012

\begin{abstract}
Using morphological and molecular data, the new species Sistotremastrum guttuliferum is described from specimens collected in the Azores archipelago, Madeira and Canary Islands. Morphologically, this new species differs from $S$. niveocremeum and S. suecicum by the small oil drops in the cytoplasm of subicular hyphae and the spore size. An updated key of Sistotremastrum species is provided.
\end{abstract}

Keywords Basidiomycota $\cdot$ Trechisporales $\cdot$ Corticioid fungi · ITS nrDNA · LSU nrDNA · Oceanic islands · Taxonomy

\section{Introduction}

The small genus Sistotremastrum (Basidiomycota, Trechisporales) was described by Eriksson (1958) to include

\author{
M. T. Telleria $(\bowtie) \cdot$ M. Dueñas $\cdot$ M. P. Martín \\ Departamento de Micología, Real Jardín Botánico, RJB - CSIC, \\ Plaza de Murillo 2, \\ 28014 Madrid, Spain \\ e-mail: telleria@rjb.csic.es \\ I. Melo \\ Jardim Botânico (MNHNC), Universidade de Lisboa/CBA-FCUL, \\ Rua da Escola Politécnica 58, \\ 1250-102 Lisbon, Portugal \\ I. Salcedo \\ Departamento de Biología Vegetal y Ecología (Botánica), \\ Universidad del País Vasco (UPV/EHU), Aptdo. 644, \\ 48080 Bilbao, Spain \\ E. Beltrán-Tejera $\cdot$ J. L. Rodríguez-Armas \\ Departamento de Biología Vegetal (Botánica), \\ Universidad de La Laguna, 38071 La Laguna, Tenerife, Spain
}

two taxa: Sistotremastrum suecicum Litsch. ex J. Erikss., as type species, and Sistotremastrum niveocremeum (Höhn \& Litsch.) J. Erikss. Both species share resupinate, adnate and effused basidioma, whitish, ceraceous when living and brittle when dried, monomitic hyphal system with clamped hyphae, basidia subclavate to tubular, with four to six sterigmata, and spores narrowly ellipsoid or subcylindrical to suballantoid.

This genus resembles Sistotrema morphologically sharing similar basidioma and number of sterigmata, but differs by the shape of basidia and hyphal inclusions. Whereas Sistotrema has urniform basidia and rich oily inclusions in all hyphal elements, Sistotremastrum is characterized by the presence of subclavate to tubular basidia and lacks oily inclusions in the hyphal elements. According to Eriksson et al. (1984), one peculiarity of Sistotremastrum is the appearance of the postmature basidia with shrunken sterigmata more or less turned inwards, a characteristic of restricted taxonomic value that could, however, be useful to distinguish specimens of the two species, because it is more evident in $S$. suecicum than in S. niveocremeum. Boidin and Gilles (1994) enlarged the concept of the genus, describing its first cystidiate species, Sistotremastrum lateclavigerum Boidin \& Gilles from France.

Within the framework of our studies about corticioid fungi from oceanic islands (Dueñas et al. 2008a, b; Melo et al. 2008; Telleria et al. 2008, 2009a, b, c, 2012) we collected several specimens in the Macaronesian region (Azores archipelago, Madeira and Canary Islands) whose characteristics lead us to include them in the genus Sistotremastrum. The aim of this study was to identify, characterize and analyze those specimens using morphological and molecular data; as result a new species is described. 


\section{Materials and methods}

Morphological studies

The study was based on specimens collected during mycological forays to the Atlantic Archipelagos of Azores, Madeira and Canary Islands, in the Macaronesian region. The collections are deposited in LISU, MA, and TFC Herbaria. Dried specimens were used for light microscope study. Colors of dried basidioma are according to ISCC_NBS Centroid Color Charts (U.S. Dept. of Commerce, National Bureau of Standards. Washington, DC). Measurements and drawings were made from microscopic sections mounted in $3 \% \mathrm{KOH}$ solution and examined at up to $\times 1,250$ with an Olympus BX51 microscope provided with a drawing tube. Lengths and widths of 30 spores and 10 basidia were measured from each sample.

Molecular analyses

Genomic DNA was extracted from three Sistotremastrum collections (10471MD, 11986MD, and 16566Tell.) using the E.Z.N.A. ${ }^{\circledR}$ Fungal DNA Miniprep Kit (Omega Biotek, Doraville, GA, USA) following the instructions of the manufacturers; samples were incubated in lysis buffer overnight at $55{ }^{\circ} \mathrm{C}$, as indicated in Martín and Winka (2000). Total DNA was used for PCR amplification and sequencing of the internal transcribed spacer region (ITS nrDNA), including the $5.8 \mathrm{~S}$ of the ribosomal RNA gene cluster and flanking parts of the small subunit (SSU) and large subunit (LSU) nuclear ribosomal genes as described in Telleria et al. (2010b). The consensus sequences have been lodged in the EMLB-EBI database with the accession numbers JX310443 (10471MD), JX310444 (11986MD), and JX310445 (16566Tell.)

These sequences were aligned using Se-Al v2.0a11 Carbon (Rambaut 2002) for multiple sequences with Trechisporales sequences retrieved from the EMBL/ GenBank/DDBJ databases (Cochrane et al. 2011). Maximum parsimony analysis (MP) using PAUP*Version 4.0b10 and Bayesian analyses using MrBayes 3.1 were carried out as indicated in Telleria et al. (2010a). The Bayesian analyses were performed assuming the general time reversible model (Rodríguez et al. 1990), including estimation of invariant sites and assuming a discrete gamma distribution with six categories $(\mathrm{GTR}+\mathrm{I}+\mathrm{G})$ as selected by MrModeltest 2.3 (Nylander 2004). Two independent and simultaneous analyses starting from different random trees were run for 2,000,000 generations with four parallel chains and trees, and model scores saved every 100th generation. The default priors in MrBayes were used in the analysis. Every 1,000th generation tree from the two runs was sampled to measure the similarities between them and to determine the level of convergence of the two runs. The potential scale reduction factor (PSRF) was used as a convergence diagnostic and the first $25 \%$ of the trees were discarded as burn-in before stationary was reached. Both the $50 \%$ majority-rule consensus tree and the posterior probability ( $p p$ ) of the nodes were calculated from the remaining trees with MrBayes. Moreover, from Sistotremastrum sequences, Kimura-2-parameter (K2P) pairwise distances were obtained using PAUP*Version 4.0b10.

\section{Results}

In both parsimony and Bayesian analyses, Sistrotremastrum sequences grouped in a separate clade from the other 49 Trechisporales sequences. Figure 1 shows the Bayesian $50 \%$ majority rule consensus tree. The ITS sequences of 10471MD, 11986MD, and 16566Tell. appeared together in a well-supported clade (bootstrap value $=99 \%$; posterior probability $=0.70)$, as sister group of a sequence from GenBank deposited as Sistotremastrum sp. (AY805625), isolate olrim558 from a Picea abies wood disc from Sweden (Menkis et al. 2004). According to Kolaczkowski and Thorton (2004), in the real world gene, sequences are not identically distributed and evolve heterogeneously, and in these cases, maximum parsimony performs better than Bayesian analyses. Moreover, due to the Farris zone, in our analyses, it seems that the topology of maximum parsimony is favored over the Bayesian one (Philippe et al. 2005). The new sequences are also separated from the sequences of $S$. niveocremeum (AF347094) and S. suecicum (EU186667). On the other hand, the K2P pairwise distance among the six Sistotremastrum sequences (651 positions) included in Table 1 gave a low value $(<0.00337)$ within the three sequences obtained in this study.

The similar morphological characters observed in these collections and the low genetic variability obtained among them, as well as the high genetic variability when comparing the sequences of these collections with those of $S$. niveocremeum and $S$. suecicum, led us to describe a new species:

Sistotremastrum guttuliferum Melo, M. Dueñas, Telleria \& M.P. Martín, sp. nov. (Fig. 2)

MycoBank: MB 800173

Diagnosis This species differs from Sistotremastrum niveocremeum and Sistotremastrum suecicum by the small oil drops in the cytoplasm of its subicular hyphae and the spore size.

Holotype PORTUGAL, MADEIRA, Santana, Levada da Fajã da Nogueira, 32 $45^{\prime} 1.59^{\prime \prime} \mathrm{N}, 16^{\circ} 54^{\prime} 56.76^{\prime \prime} \mathrm{W}, 780 \mathrm{~m}$ asl, on unidentified wood, 19.10.2006, 16566Tell. (MA-Fungi 82105). 
Fig. 1 The ITS nrDNA Bayesian $50 \%$ majority rule consensus trees. In every collapsed clade, the number of sequences is indicated in the triangle. The percentages of bootstraps superior to $50 \%$ (Felsenstein 1985) and the posterior probabilities superior to 0.50 (Ronquist and Huelsenbeck 2003) are indicated. The position of Sistotremastrum guttuliferum sp. nov. is highly supported (bs $=90 \%, p p=0.70$ )

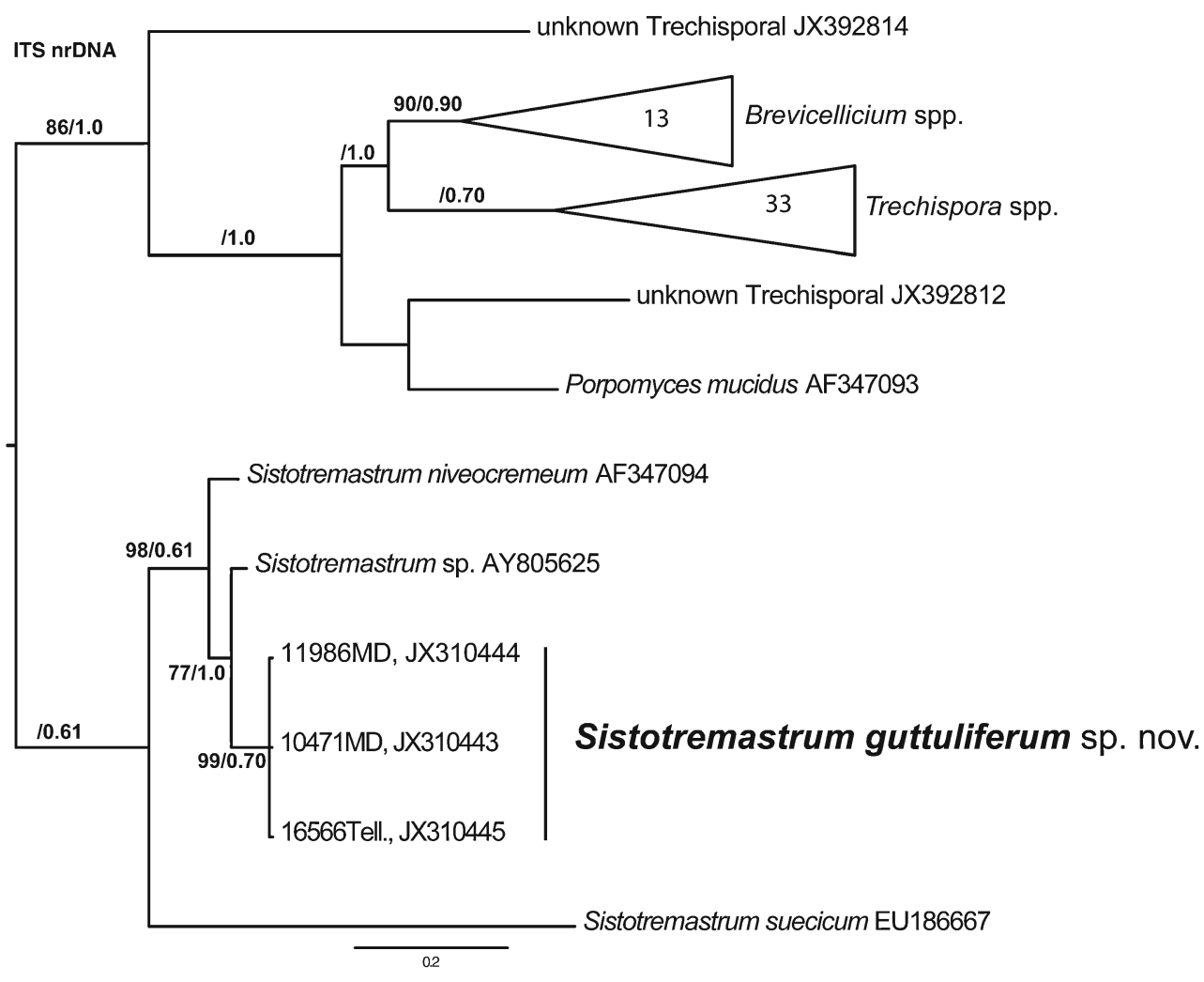

Basidioma resupinate, effuse, adnate, thin, ceraceous to membranaceous; hymenophore whitish cream, when dry pale ochraceous, first almost smooth, under the lens porose, then more or less odontioid, after drying cracked transversally; margin indeterminate, gradually thinning out, in the periphery porose to pruinose. Hyphal system monomitic, hyphae with clamps, distinct, in the subiculum irregularly interwoven, thick-walled, 4-7(-10) $\mu \mathrm{m}$ wide, with small oil drops in the cytoplasm, in the subhymenium thinner, densely united, all with vertical hyphal direction. Basidia subclavate to subtubular, sometimes slightly constricted, walls thin but basally somewhat thickened, $15-20(-25) \times(5-) 6-$ $7.5 \mu \mathrm{m}$, with six short sterigmata. Spores narrowly ellipsoid, thin-walled, 5-6.5 $\times 2.5-3 \mu \mathrm{m}$, without oil drops in the protoplasm, inamyloid, indextrinoid, and acyanophilous.

Material examined PORTUGAL, AZORES ARCHIPELAGO, Faial Island, Horta, Capelo, Cabeço Verde, Furna Ruim, $38^{\circ} 35^{\prime} 36.40^{\prime \prime} \mathrm{N}, 28^{\circ} 48^{\prime} 9.55^{\prime \prime} \mathrm{W}, 400 \mathrm{~m}$ asl, Erica azorica, 23. 2. 2005, 16097Tell. (MA-Fungi 76166); Horta, Ponta do Varadouro, 38 $34^{\prime} 23.01^{\prime \prime} \mathrm{N}, 28^{\circ} 46^{\prime} 43.04^{\prime \prime} \mathrm{W}, 42 \mathrm{~m}$ asl, Picconia azorica, 21.2.2005, 10471MD (MA-Fungi 82100). Flores Island, St. ${ }^{a}$ Cruz das Flores, Vales, 39 $26^{\prime}$ $48.8^{\prime \prime} \mathrm{N}, 31^{\circ} 09^{\prime} 07.8^{\prime \prime} \mathrm{W}, 245 \mathrm{~m}$ asl, Pittosporum undulatum, 26.3.2007, 17391 Tell. (MA-Fungi 76283), 17392Tell. (MAFungi 76284); St. ${ }^{a}$ Cruz das Flores, Barrocas Altas, Chapel of N. ${ }^{a}$ Sr. ${ }^{a}$ das Flores, 39 $26^{\prime} 17.24^{\prime \prime} \mathrm{N}, 31^{\circ} 11^{\prime} 50.18^{\prime \prime} \mathrm{W}$, $580 \mathrm{~m}$ asl, Cryptomeria japonica, 27.3.2007, 10312IM, (LISU 211124), 10313IM, (LISU 211125), 17453Tell. (MA-Fungi 76285); St. ${ }^{a}$ Cruz das Flores, Alagoa, 39²8' 26.7"N, 31 ${ }^{\circ} 09^{\prime} 47.1^{\prime \prime} \mathrm{W}, 180 \mathrm{~m}$ asl, Pittosporum undulatum, 27.3.2007, 11830MD, (MA-Fungi 76297), (TFCMic 18367); St. ${ }^{\text {a }}$ Cruz das Flores, Fazenda de St. ${ }^{a}$ Cruz, Ribeira da Fazenda, 39²7'21.56"N, 31 ${ }^{\circ} 9^{\prime} 27.36^{\prime \prime} \mathrm{W}, 215 \mathrm{~m}$ asl, Acacia sp., 28.3.2007, 10352IM, (LISU 211126), ibidem, Pittosporum undulatum, 28.3.2007, 11851MD (MA-Fungi
Table 1 Matrix of pairwise intra- and inter-specific Kimura2-parameter (K2P) distance matrix among Sistotremastrum ITS nrDNA sequences

\begin{tabular}{llllllll}
\hline & & 1 & 2 & 3 & 4 & 5 & 6 \\
\hline 1 & S. suecicum EU186667 & - & & & & \\
2 & S. niveocremeum AF347094 & 0.19553 & - & & & \\
3 & Sistotremastrum sp. AY805625 & 0.33214 & 0.05767 & - & & \\
4 & S. guttuliferum 10471MD, JX310443 & 0.29736 & 0.07762 & 0.05405 & - & \\
5 & S. guttuliferum 16566Tell., JX310445 & 0.29393 & 0.07797 & 0.05615 & 0.00331 & - \\
6 & S. guttuliferum 11986MD, JX310444 & 0.29912 & 0.08153 & 0.05601 & 0.00167 & 0.00337 & - \\
\hline
\end{tabular}


Fig. 2 Sistotremastrum guttuliferum (holotype, 16566Tell., MA-Fungi 82105) a Section through fruit-body; b subicular hyphae; c subhymenial hyphae; d hymenium; e basidia; $\mathbf{f}$ spores

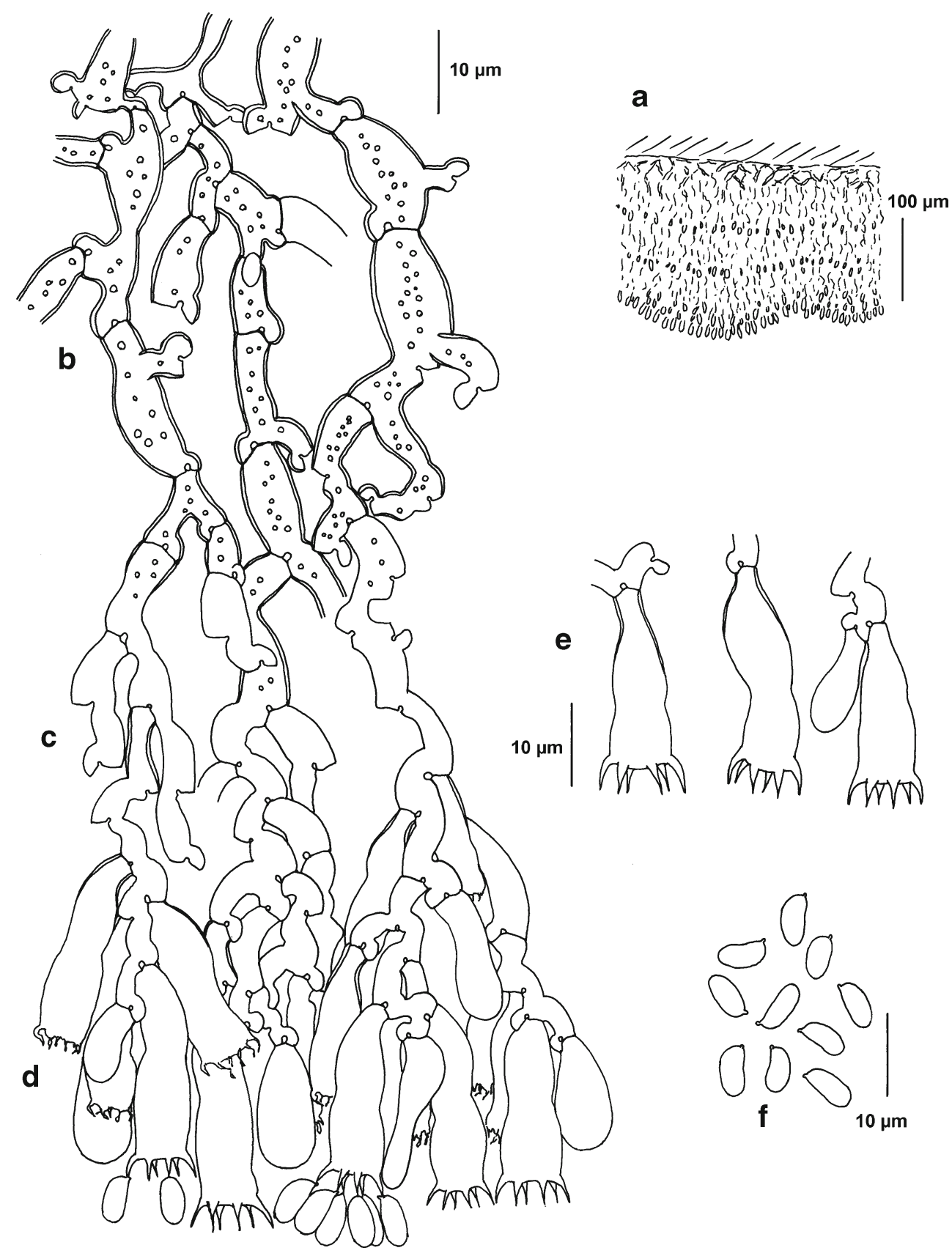

75895); Lajes das Flores, next to Fazenda de Lajes, 39² $24^{\prime}$ $08.7^{\prime \prime} \mathrm{N}, 31^{\circ} 11^{\prime} 17.5^{\prime \prime} \mathrm{W}, 400 \mathrm{~m}$ asl, Erica scoparia, 27.3.2007, 17417Tell. (MA-Fungi 76282). Pico Island, São Roque, Mistério da Prainha, 38 $29^{\prime} 0.40^{\prime \prime} \mathrm{N}, 28^{\circ} 14^{\prime}$ 27.96"W, Pittosporum undulatum, 25.2.2005 (TFCMic 15275); São Roque, Meia Encosta de Santa Luzia, Travessa de Cima, 38 $30^{\prime} 49.96^{\prime \prime} \mathrm{N}, 28^{\circ} 22^{\prime} 51.32^{\prime \prime} \mathrm{W}, 600 \mathrm{~m}$ asl, Myrica faya, 26.2.2005, 10590MD (MA-Fungi 76101), (TFCMic 15302); ibidem, Pittosporum undulatum, 26.2.2005, (TFCMic 15290). S. Miguel Island, Nordeste, Outeiro Alto, Miradouro da Tronqueira, 37³7'06.1"N, $25^{\circ} 11^{\prime} 54.2^{\prime \prime} \mathrm{W}, 386 \mathrm{~m}$ asl, Laurus azorica (TFCMic 18508); Vila Franca do Campo, Água de Alto, Ribeira da Praia, 37 $43^{\prime} 57.15^{\prime \prime} \mathrm{N}, 25^{\circ} 28^{\prime} 10.26^{\prime \prime} \mathrm{W}, 215 \mathrm{~m}$ asl, Acacia sp., 29.3.2007, 10382IM (LISU 211127); Ribeira Grande, near Caldeiras, $37^{\circ} 48^{\prime} 1.21^{\prime \prime} \mathrm{N}, 2^{\circ} 29^{\prime} 23.94^{\prime \prime} \mathrm{W}, 220 \mathrm{~m}$ asl, Acacia sp., 30.3.2007, 10417IM (LISU 211128), 10421IM (LISU 211129); ibidem, Pittosporum undulatum, 31.3.2007, 17533Tell. (MA-Fungi 76287); Ponta Delgada, Capelas, near Pico do Cedro, 3749'6.74"N, 2542'11.36"W, $310 \mathrm{~m}$ asl, Acacia sp., 1.4.2007, 10525IM (LISU 211130), 10532IM (LISU 211131); ibidem, Pittosporum undulatum, 
11986MD (MA-Fungi 82107). Terceira Island, Angra do

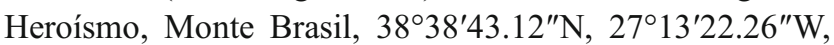
$140 \mathrm{~m}$ asl, Pittosporum undulatum, 2.3.2005, 16228Tell. (MA-Fungi 76140), 9109IM (LISU 178604); Angra do Heroísmo, near Algar do Carvão, Terra Brava, 38 $44^{\prime}$ $22.41^{\prime \prime} \mathrm{N}, 27^{\circ} 12^{\prime} 24.70^{\prime \prime} \mathrm{W}, 670 \mathrm{~m}$ asl, unidentified wood, 1.3.2005, 16212Tell. (MA-Fungi 76128). - MADEIRA, Porto Moniz, Fanal, $32^{\circ} 48^{\prime} 52.58^{\prime \prime} \mathrm{N}, 17^{\circ} 08^{\prime} 51.09^{\prime \prime} \mathrm{W}, 1135 \mathrm{~m}$ asl, Ocotea foetens, 22.10.2006, 9480IM (LISU 211313); Santana, Levada da Fajã da Nogueira, $32^{\circ} 45^{\prime} 1.59^{\prime \prime} \mathrm{N}, 16^{\circ} 54^{\prime}$ 56.76"W, $780 \mathrm{~m}$ asl, Erica scoparia, 19.10.2006, 16565Tell. (MA-Fungi 82104), 16567Tell. (MA-Fungi 82106); Machico, Portela, from Portela to Funduras, $32^{\circ} 45^{\prime} 2.95^{\prime \prime} \mathrm{N}, 16^{\circ} 48^{\prime}$ 41.64"W, $600 \mathrm{~m}$ asl, Pinus pinaster, 18.10.2006, 16353Tell. (MA-Fungi 82103); ibidem, unidentified wood, 16337Tell. (MA-Fungi 82102). - SPAIN. CANARY ISLANDS, La Gomera Island, Hermigua, Parque Nacional de Garajonay, Monte de El Cedro, Las Mimbreras, 28 $07^{\prime} 36.53^{\prime \prime} \mathrm{N}, 17^{\circ} 13^{\prime} 16.74^{\prime \prime} \mathrm{W}$, $947 \mathrm{~m}$ asl, Laurus novocanariensis, 2.2.2007, 10105IM (LISU 240482), 10104IM (LISU 240481). Tenerife Island, El Rosario, road La Laguna to Las Cañadas del Teide, pista del Bailadero, next to Las Lagunetas, $28^{\circ} 24^{\prime} 57.58^{\prime \prime} \mathrm{N}, 16^{\circ} 24^{\prime}$ 09.52"W, 1,400 m asl, Pinus canariensis, 31.1.2007, 11550MD (MA-Fungi 82101).

Etymology Referring to oil drops in the cytoplasm of hyphal elements.

Known distribution Macaronesian region: Azores Archipelago, Madeira and Canary Islands.

From a morphological point of view, the new species is characterized by the small oil drops in the cytoplasm of subicular hyphae. It differs from Sistotremastrum niveocremeum by the size and shape of spores, subcylindrical to allantoid, 6-9 $62.5-3(-4) \mu \mathrm{m}$ in this last species and narrowly ellipsoid, 5-6.5 $\times 2.5-3 \mu \mathrm{m}$ in Sistotremastrum guttuliferum. The spores of Sistotrematrum suecicum are also narrowly ellipsoid but differ by size, $4.5-6 \times 1.5-2 \mu \mathrm{m}$.

\section{Key to species}

1. Cystidia present (leptocystidia)

1. Cystidia absent

2. Subicular hyphae with oil drops in the cytoplasm. Spores narrowly ellipsoid, $5-6.5 \times 2.5-3 \mu \mathrm{m}$

2. Subicular hyphae without oil drops

in the cytoplasm

3. Spores subcylindrical to allantoid, $6-9 \times 2.5-3(-4) \mu \mathrm{m}$

3. Spores narrowly ellipsoid, $4.5-6 \times 1.5-2 \mu \mathrm{m}$ long
Acknowledgments Thanks to Markus Göker (Liebniz Institute DSMZ, Germany) and an anonymous reviewer for discussion related to maximum parsimony bootstrap and Bayesian posterior probabilities supports. We are also grateful to Marian Glenn (Seton Hall University, New Jersey) for checking the English and Fátima Durán (RJB-CSIC) for providing technical assistance. Financial support was provided by DGI project CGL2009-07231

\section{References}

Boidin J, Gilles G (1994) Contribution à la connaissance des corticiés à basides urniformes ou suburniformes (Basidiomycotina). Bull Soc Mycol Fr 110:185-229

Cochrane G, Karsch-Mizrachi I, Nakamura Y (2011) The International Nucleotide Sequence Database Collaboration. Nucleic Acids Res 39:D15-D18. doi:10.1093/nar/gkr1006

Dueñas M, Telleria MT, Melo I, Martín MP (2008a) Lagarobasidium calongei (Aphyllophorales, Basidiomycota), a new species of corticioid fungi from Azores Islands. An Jard Bot Madrid 66S1:41-46

Dueñas M, Telleria MT, Melo I, Rodríguez-Armas JL, Beltrán-Tejera E (2008b) A new species of Candelabrochaete (Polyporales, Basidiomycota). Mycotaxon 103:299-305

Eriksson J (1958) Studies in the Heterobasidiomycetes and Homobasidiomycetes-Aphyllophorales of Muddus National Park in North Sweden. Symb Bot Ups 16(1):1-172

Eriksson J, Hjortstam K, Ryvarden L (1984) The Corticiaceae of North Europe Vol. 7. Schizopora-Suillosporium. Fungiflora, Oslo

Felsenstein J (1985) Confidence limits on phylogenies: an approach using the bootstrap. Evolution 39:783-791. doi:10.2307/2408678

Kolaczkowski B, Thorton JW (2004) Performance of maximum parsimony and likelihood phylogenetics when evolution is heterogeneous. Nature 431:980-984

Martín MP, Winka K (2000) Alternative methods of extracting and amplifying DNA from lichens. Lichenologist 32:189-196. doi:10.1006/lich.1999.0254

Melo I, Dueñas M, Telleria MT (2008) Repetobasidium azoricum (Basidiomycotina, Sistotremaceae), a new species from Azores Islands. Syn Fung 25:6-10

Menkis A, Allmer J, Vasiliauskas R, Lygis V, Stenlid J, Finlay R (2004) Ecology and molecular characterization of dark septate fungi from roots, living stems, coarse and fine woody debris. Mycol Res 108:965-973

Nylander JAA (2004) MrModeltest v2. Program Distributed by the Author. Uppsala University

Philippe H, Zhou Y, Brinkmann H, Rodrigue N, Delsuc F (2005) Heterotachy and long-branch attraction in phylogenetics. BMC Evol Biol 5:50. doi:10.1186/1471-21-48-5-50

Rambaut A (2002) Se-A1: sequences alignment editor v2.0a11. Institute of Evolutionary Biology, University of Edinburgh. http://tree.bio.ed.ac.uk/software

Rodríguez F, Oliver JF, Martin A, Medina JR (1990) The general stochastic model of nucleotide substitution. J Theor Biol 142:485-501

Ronquist F, Huelsenbeck JP (2003) MrBayes 3: Bayesian phylogenetic inference under mixed models. Bioinformatics 19:1572-1574

Telleria MT, Dueñas M, Beltrán E, Rodríguez-Armas JL, Melo I (2008) Gloeodontia xerophila (Aphyllophorales, Basidiomycota), a new species with corticioid basidioma 
from Canary Islands. Mycologia 100:673-676. doi:10.3852/ 07-200R1

Telleria MT, Melo I, Dueñas M, Rodríguez-Armas JL, Beltrán-Tejera E, Cardoso J, Salcedo I (2009a) Diversity and richness of corticioid fungi (Basidiomycota) on Azores Islands: a preliminary survey. Nova Hedwigia 88:285-308. doi:10.1127/0029-5035/ 2009/0088-0285

Telleria MT, Melo I, Dueñas M, Salcedo I, Cardoso J, RodríguezArmas JL, Beltrán-Tejera E (2009b) Corticioid fungi (Basidiomycota) from Madeira Island. Mycotaxon 106:419-422

Telleria MT, Melo I, Dueñas M, Salcedo I, Cardoso J, Rodríguez-Armas JL, Beltrán-Tejera E (2009c) Corticioid fungi (Basidiomycota) from
Azores Islands: Flores and São Miguel. Mycotaxon 109:141-144. doi:10.5248/109.141

Telleria MT, Dueñas, M, Melo I, Hallenberg N, Martín MP (2010a) A re-evalution of Hypochnicium (Polyporales) based on morphological and molecular characters. Mycologia 102:1426-1436. doi:10.3852/09-242

Telleria MT, Dueñas M, Melo I, Martín MP (2010b) Morpholigical and molecular studies of Hyphodermella in the western Mediterranean area. Mycol Prog 9:585-596

Telleria MT, Dueñas, M, Melo I, Beltrán-Tejera E, Rodríguez-Armas JL, Salcedo I, Martín MP (2012). Gloeocystidiellum kenyense in Azores and Madeira. Mycotaxon 119:337-343. doi:10.5248/119.337 